\title{
Determination of environmentally relevant exposure concentrations of polybrominated diphenyl ethers for in vitro toxicological studies
}

\author{
Rong-Guo Wei ${ }^{\text {a }}$ Ya-Xian Zhao ${ }^{\mathrm{a}, \mathrm{b}}$, Peng-Yan Liu ${ }^{\mathrm{b}}$, Zhan-Fen Qin ${ }^{\mathrm{a}, *}$, Shi-Shuai Yan ${ }^{\mathrm{a}}$, Yan Li ${ }^{\mathrm{a}, \mathrm{b}}$, \\ Xiao-Fei Qin ${ }^{\mathrm{a}}$, Xi-Juan Xia ${ }^{\mathrm{a}}$, Xiao-Bai Xu ${ }^{\mathrm{a}}$, Min-Chan Yan $^{\mathrm{c}}$ \\ a State Key Laboratory of Environmental Chemistry and Ecotoxicology, Research Center for Eco-environmental Sciences, Chinese Academy of Sciences, Beijing, China \\ ${ }^{\mathrm{b}}$ College of Chemistry and Environmental Science, HeBei University, Baoding, Hebei, China \\ ${ }^{\mathrm{c}}$ Taizhou Hospital, Taizhou City, Zhejiang Province 317000, China
}

\section{A R T I C L E I N F O}

\section{Article history:}

Received 27 December 2009

Accepted 25 March 2010

Available online 31 March 2010

\section{Keywords:}

Polybrominated diphenyl ethers

Environmentally relevant

In vitro

Cells

\begin{abstract}
A B S T R A C T
Toxicological studies at environmentally relevant concentrations are essential for understanding ecotoxic and health risks of pollutants such as polybrominated diphenyl ethers (PBDEs). However, no information is available on what exposure levels of PBDEs in vitro studies are environmentally relevant. We exposed MCF-7, HepG2, H295R and PC12 cells to BDE-47, and measured BDE-47 concentrations in the cells after exposure. We also used the percentile method to summarize literature data on environmental exposure levels of biotic tissues to PBDEs. The exposure concentration that resulted in a BDE-47 burden in cells close to the 90th percentile of PBDEs levels in tissues was assigned as the upper limit for the environmentally relevant concentration. Exposure to $1 \mathrm{nM}$ BDE-47 resulted in PBDEs burdens in MCF-7, HepG2 and H295R cells close to the 90th percentile but PBDEs burdens in PC12 cells were higher than the 90th percentile. In consideration of the high exposure levels in PBDE-polluted areas, we concluded that the highest environmentally relevant exposure concentration of PBDEs in culture media should be approximately $10 \mathrm{nM}$ for MCF-7, HepG2 and H295R cells, and <10 nM for PC12 cells. These results provide an approximate reference for setting environmentally relevant exposure concentrations of PBDEs for studies in vitro.
\end{abstract} (c) 2010 Elsevier Ltd. All rights reserved.

\section{Introduction}

Polybrominated diphenyl ethers (PBDEs) are a class of flame retardants used extensively in a variety of commercial and household products, such as electronic equipment, plastics, construction materials, coatings and textiles (Costa and Giordano, 2007; Stapleton et al., 2009). PBDEs have been found in various environmental and biotic samples, including human tissues (Alcock et al., 2003; Costa and Giordano, 2007; Darnerud et al., 2001; Stapleton et al., 2009; Watanabe and Sakai, 2003). In recent years, the potential adverse effects of PBDEs in animals and humans have caused increasing concern. Numerous studies have shown that PBDEs and polychlorinated biphenyls (PCBs) have a wide range of toxicities, such as thyroid disrupting activity and developmental neurotoxicity (Costa and Giordano, 2007; Hallgren and Darnerud, 2002; Harju et al., 2007; Song et al., 2009).

\footnotetext{
Abbreviations: BDE-47, 2,2',4,4'-tetrabrominated diphenyl ether; DMEM, Dulbecco's modified Eagle's medium; DMSO, dimethyl sulfoxide; FBS, fetal bovine serum; PBDEs, polybrominated diphenyl ethers.

* Corresponding author. Address: P.O. Box 2871, Research Center for EcoEnvironmental Sciences, Chinese Academy of Sciences, Beijing 100085, China. Tel.: +8610 62919177; fax: +861062923563.

E-mail address: qinzhanfen@rcees.ac.cn (Z.-F. Qin).
}

To date, available information on PBDEs toxicity has mainly been derived from studies at high doses, which are generally several orders of magnitude higher than actual environmental exposure levels for animals and humans (Suvorov and Takser, 2008). There is limited information on adverse effects of PBDEs in animals and humans at low doses and especially at environmentally relevant doses. High dose studies have predominated in toxicology because scientists assume these studies can indicate the target of low dose exposure. However, some environmental toxicants display non-linear dose-response relationships, which means they cause different effects at different doses, and the impacts at low doses may not occur at high doses (Andrade et al., 2006; Narita et al., 2007; Wetherill et al., 2002; Wozniak et al., 2005). Recently, PBDEs have been reported to display apparent non-monotonic effects in experimental rats. Suvorov et al. (2008) found that exposure to a low dose $(2 \mu \mathrm{g} / \mathrm{kg})$ of $2,2^{\prime}, 4,4^{\prime}$-tetrabrominated diphenyl ether (BDE-47) seemed to more effectively induce hyperactivity in rat offspring compared to high doses (20 and $200 \mu \mathrm{g} / \mathrm{kg}$ ). Talsness et al. (2008) reported that exposure to low doses of BDE-47 $(140 \mu \mathrm{g} / \mathrm{kg}$ body weight) caused an increase in ovarian weight in experimental rats but high doses $(700 \mu \mathrm{g} / \mathrm{kg})$ had no significant effect. Therefore, toxicological studies at doses higher than environmental exposure levels might contribute little to the 
understanding of ecotoxic and health risks associated with PBDEs. Therefore, toxicological studies at environmentally relevant doses are essential.

In vitro studies are important in toxicology and are frequently used to study PBDEs toxicity. In general, previous studies of PBDEs in vitro have incorporated micromolar $(\mu \mathrm{M})$ levels in the culture media, although several reports have used nanomolar (nM) levels (Barber et al., 2006; Cantón et al., 2006; Dingemans et al., 2007, 2008; Fery et al., 2009; Giordano et al., 2008, 2009; He et al., 2008a,b, 2009; Hu et al., 2007; Madia et al., 2004; Mercado-Feliciano and Bigsby, 2008; Peters et al., 2004, 2006; Stavenes Andersen et al., 2009; Song et al., 2009; Stapleton et al., 2009; Tagliaferri et al., 2010; Zhang et al., 2007). None of these studies measured the cellular PBDE concentrations but it is assumed that the concentrations used may not be environmentally relevant because they are much higher than the picomolar (pM) or lower levels typically found in environmental water or body fluids (Frederiksen et al., 2009; Gill et al., 2004; Streets et al., 2006; Wu et al., 2008). It is important to establish exposure concentrations of PBDEs for in vitro toxicological studies that will result in environmentally relevant concentrations in culture cells. Human breast carcinoma MCF-7 cells, human adrenocortical carcinoma H295R cells, human hepatoma HepG2 cells and rat pheochromocytoma PC12 cells are the most commonly used cells in PBDEs toxicological studies. In this study, we exposed culture cells to BDE-47, which is a main PBDEs component in various environmental and biotic samples, and investigated its accumulation in the cells. As the available literature on environmental exposure levels of PBDEs in biotic tissues had not been summarized previously, we used the percentile method to do this. Based on the 90th percentile level of PBDEs, we determined the PBDEs exposure concentration that would result in environmentally relevant burdens in cells for studies in vitro.

\section{Materials and methods}

\subsection{Chemicals}

BDE-47 was obtained from Dr. Ehrenstorfer GmbH (Augsburg, Germany). Dimethyl sulfoxide (DMSO) and dextran were purchased from Sigma-Aldrich Chemical Co. (St. Louis, MO). Trypsinase was purchased from Invitrogen (Steinheim, Germany). Dulbecco's modified Eagle's medium (DMEM) was purchased from Invitrogen (Carlsbad, CA). All other consumables for cells were obtained from Invitrogen Life Technologies, unless otherwise stated.

Solutions of BDE-71 for use as a surrogate standard and EO5278 to quantify the BDE-71 were purchased from Cambridge Isotope Laboratories (Andover, MA). Pesticide grade $n$-hexane, methylene dichloride, and nonane were purchased from Tedia (Fairfield, $\mathrm{OH}$ ). Anhydrous sodium sulfate, sulfuric acid, sodium hydroxide, and anhydrous ethanol (Beijing Chemical Factory, Beijing, China) were of analytical grade.

\subsection{Cell culture}

HepG2 cells (Cell Bank of Chinese Academy of Sciences) were cultured in DMEM containing 10\% fetal bovine serum (FBS, Hyclone). Rat pheochromocytoma PC12 cells (Cell Bank of Chinese Academy of Sciences) were cultured in DMEM supplemented with 7.5\% FBS and 7.5\% horse serum (Hyclone). MCF-7 cells (ER human mammary carcinoma), kindly provided by Professor Ana M. Soto (Tufts University School of Medicine), were cultured in DMEM containing 5\% FBS. H295R adrenocortical carcinoma cells (ATCC, Manassas, VA) were cultured in a 1:1 mixture of DMEM and Ham's F-12 Nutrient mixture (Sigma-Aldrich Chemical Co., St. Louis, MO), supplemented with 1\% Insulin Transferrin Selenium (ITS) (BD Biosciences, San Jose, CA) Premix, 2.5\% Nu-Serum (BD Biosciences), and $1.2 \mathrm{~g} / \mathrm{L} \mathrm{Na}_{2} \mathrm{CO}_{3}$. HepG2, MCF-7 and H295R were grown in $25 \mathrm{~cm}^{2}$ cell culture flasks (Corning, United States), while PC12 were grown in $25 \mathrm{~cm}^{2}$ cell culture flasks coated with $50 \mathrm{mg} / \mathrm{mL}$ of polyL-lysine (Sigma-Aldrich Chemical Co.). All cells were cultured under a humidified atmosphere of $5 \% \mathrm{CO}_{2} / 95 \%$ air at $37{ }^{\circ} \mathrm{C}$, and subcultured upon reaching $80-90 \%$ confluence.

\subsection{Exposure of cells to $B D E-47$}

A stock solution of BDE-47 $(1 \mathrm{mg} / \mathrm{mL})$ was prepared in DMSO, and diluted with culture medium to a range of concentrations $(0.1-100 \mathrm{nM})$ for treatments. In all cases, the DMSO volume was no more than $0.001 \%$ of the total volume. The vehicle control cells were exposed to $0.001 \%$ DMSO.

All cells were trypsinized and plated in $25 \mathrm{~cm}^{2}$ cell culture flasks (without poly-L-lysine coating) at a seeding density of $1.5 \times 10^{4}$ cells $/ \mathrm{mL}$ (except for PC12) with the culture media containing a range of concentrations of BDE-47. The seeding density of PC12 was $3.3 \times 10^{4}$ cells $/ \mathrm{mL}$ and $2.6 \times 10^{4}$ cells $/ \mathrm{mL}$ for 3 days and 6 days, respectively. Exposure times were generally within 6 days in the most of previous in vitro studies (Barber et al., 2006; Fery et al., 2009; He et al., 2008a,b; Hu et al., 2007; Peters et al., 2004, 2006; Song et al., 2009). So, we chose 3 days and 6 days as exposure time in this study. The culture medium was changed every 3 days. Each treatment was carried out twice with two replicate flasks each time.

\subsection{Collection and extraction of cell samples}

After 3 days or 6 days, the cells were collected according to the following method. Firstly, the culture medium was removed from the flask. Culture flasks and attached cells were then washed with phosphate buffered saline (PBS) three times. The cells were trypsinized and transferred to clean glass centrifuge tubes, followed by centrifugation at $1000 \mathrm{rpm}$ for $5 \mathrm{~min}$. Harvested cells were allowed to air dry and then weighed. The cell samples were spiked with BDE-71 as a surrogate standard. The mixture sample was extracted by sonicating twice in $15 \mathrm{~mL}$ of hexane for a period of $4 \mathrm{~min}$, followed by centrifugation. Lipids were removed from the extracts with $8 \mathrm{~g}$ of acidified silica gel (44\% concentrated sulfuric acid, w/w), and the PBDE mixture was then eluted with $100 \mathrm{~mL}$ of hexane. The extract was concentrated to $2 \mathrm{~mL}$ using a rotary evaporator, and then concentrated further to approximately $0.1 \mathrm{~mL}$ under a nitrogen stream. Finally, the extract was transferred to GC vials. Throughout the extraction, cleanup and analysis procedure, amber glassware or aluminum foil wrapping was used to protect the analytes from light.

\subsection{PBDEs analysis}

All samples were analysed for PBDEs by an Agilent model 6890N gas chromatograph coupled with a model 5973i mass spectrometer (GC/MS) (Agilent Technologies, Palo Alto, CA) using electron-capture negative-ionization (ECNI) in the selected-ion monitoring mode. The GC/MS operating conditions were as described by Liang et al. (2008). The ions monitored for BDE-47 were $\mathrm{m} / \mathrm{z} 79$ and 81 (bromide ions) in the GC/ECNI-MS mode. BDE-47 was quantified using an external standard (EO-5278) with a multi-level calibration curve spanning the range of anticipated analyte concentrations in the samples. 


\subsection{Quality assurance and quality control}

Recovery of the BDE-71 surrogate standard ranged from $90 \%$ to $100 \%$, therefore analyte values were not corrected for recovery. A procedural blank was run in parallel with every batch of six samples. The limit of detection (LOD) was based on the peak-to-peak noise of the baseline near the analyte peak of a spiked sample. LOD for BDE-47, defined as a signal of three times the noise level, was $0.06 \mathrm{ng} / \mathrm{g}$ wet-weight in the present study.

\subsection{Literature data on environmental exposure levels of biotic tissues to PBDEs}

We conducted a literature search (keyword, PBDEs; limits, animals and humans; date, September 28, 2009) of the National Library of Medicine (NLM) PubMed database for all articles addressing PBDEs levels in biotic samples. There are the inter-species and inter-tissues differences in PBDE bioaccumulation. Based a great deal of data, however, PBDEs concentrations in various biotic tissues are mainly related to background exposure levels of PBDEs rather than biological difference among species and tissues. Therefore, inter-species and inter-tissues difference was neglected to give an overview of PBDEs concentrations in biotic tissues in this study as well as other reports (Gauthier et al., 2008; Helgason et al., 2009; Hites, 2004; Shaw and Kannan, 2009; Tanabe et al., 2008). From the results of this search, we selected papers that reported PBDEs concentrations on a wet-weight basis in biotic tissues, including liver, brain, blood, and kidney. Data on fat and egg were excluded because these two tissues are not generally considered as targets of toxicants. We also excluded any data from the whole body of some animals, such as fish. This was due to the potential overestimation of PBDEs burdens in these biotic samples because the PBDEs could be absorbed by the body surface but not enter the body tissues. In addition, data from a laboratory experiment were also excluded from the subsequent analysis as we only included data from natural environments. Forty papers met our selection criteria and were retained for analysis (Table 1). Most of the data were related to the general environment, while some data were from environments polluted with PBDEs from production, application or disposal. PBDEs levels in biotic tissues from polluted regions are obviously higher than those from the general environment, and consequently we summarized the data from these environments separately. The percentile method is a useful method for estimating background concentrations of chemical pollutants in biotic and environmental samples (Chen et al., 2010; Isosaari et al., 2006). The 90th percentile level as well as the 95th percentile level is used to estimate the upper extremes of pollutant concentrations. In this study, we used this method to summarize the environmental exposure levels of PBDEs because PBDEs concentrations among various biotic tissues varied by orders of magnitude. The 25th, 50th, 75th and 90th percentiles of PBDEs levels were calculated in each group using Microsoft Excel. We used minimum and maximum PBDEs values to calculate the percentiles if primary data of PBDEs was unavailable in some cases. The 90th percentile of PBDEs levels was assigned as the upper limit of the environmental exposure levels of PBDEs in biotic tissues. The exposure concentration in culture media that resulted in a BDE-47 burden in cells close to the 90th percentile of PBDEs levels was assigned as the approximate upper limit of the environmentally relevant concentration.

\subsection{Data analysis}

All statistical analyses were performed using Microsoft Excel XP and SPSS software version 13.0 (SPSS Inc., Chicago, IL). One-way ANOVA was used to test significant differences between PBDEs accumulation in the cells. A $p$-value of $<0.05$ was considered significant.

\section{Results}

Only minimal amounts of lower brominated congeners arising from BDE-47 were found in all cell samples. We did not analyse samples for BDE-47 metabolites because the in vitro metabolism of BDE-47 has been reported to be minimal, even in hepatocytes (Stapleton et al., 2009). Therefore, the PBDEs burdens in cells that we report are BDE-47 concentrations. Exposure of the cells to 0.1$100 \mathrm{nM}$ BDE-47 in the culture medium resulted in a concentrationdependent accumulation in the cells (Table 2, Fig. 1). BDE-47 burdens in all cells were at ppb levels $(0.96-142.70 \mathrm{ng} / \mathrm{g}$ ) following both 3 days and 6 days of exposure to 0.1-1 nM BDE-47. BDE-47 concentrations in PC12 cells were higher than those in other cells. Following $10 \mathrm{nM}$ exposure, BDE-47 concentrations in PC12 cells reached ppm levels (1557.67-1757.43 ng/g), while remaining at ppb levels (204.56-726.68 ng/g) in the other cell lines. After exposure to $100 \mathrm{nM}$ BDE-47 for 3 days, BDE-47 concentrations in all cells reached ppm levels (2897.24-6263.29 ng/g). BDE-47 concentrations in all cells following exposure for 6 days were too high to measure BDE-47 concentrations. We did not measure this dose by further diluting because all we consider was which dose was environmentally relevant. Time-dependent accumulation was observed in all cells except for PC12 cells, with exposure for 6 days resulting in higher burdens than exposure for 3 days (Fig. 2). In comparison, BDE-47 burdens in PC12 cells were nearly equivalent after both 3 and 6 days of exposure to each concentration.

PBDEs levels in biotic tissues vary widely from 0 to $2687 \mathrm{ng} / \mathrm{g}$ wet-weight (Table 1 ). The 25 th, 50 th, 75 th and 90th percentiles of PBDEs levels were $0.16,1.81,10.68$ and $55.35 \mathrm{ng} / \mathrm{g}$, respectively, in the general environment, and 6.90, 48.20, 436.00 and $675.30 \mathrm{ng} /$ $\mathrm{g}$, respectively, in polluted regions (Table 3 ). After exposure to $1 \mathrm{nM}$ BDE-47 for 3 days, BDE-47 concentrations in MCF-7, HepG2 and H295R cells were $18.21,27.5$ and $18.14 \mathrm{ng} / \mathrm{g}$, respectively. While after exposure for 6 days, BDE-47 concentrations in MCF-7, HepG2 and H295R cells were 43.26, 52.15 and $43.46 \mathrm{ng} / \mathrm{g}$, respectively, which were comparable to the 90th percentile in the general environment $(55.35 \mathrm{ng} / \mathrm{g}$, Table 3$)$. Therefore, approximately $1 \mathrm{nM}$ and lower concentrations in culture media were determined to be relevant to general environmental exposure of biotic tissues to PBDEs. However, exposure of PC12 cells to $1 \mathrm{nM}$ BDE- 47 for 3 days and 6 days resulted in BDE-47 burdens of 128.47 and $142.70 \mathrm{ng} / \mathrm{g}$, respectively (Table 3 ). These results are two to three times higher than the 90th percentile in the general environment $(55.35 \mathrm{ng} / \mathrm{g}$ ). Therefore, for PC12 cells the environmentally relevant exposure level should be lower than $1 \mathrm{nM}$ in the culture medium. When considering exposure levels of PBDEs in polluted regions, the environmentally relevant concentrations were determined to be approximately $10 \mathrm{nM}$ and lower for MCF-7, HepG2 and H295R cells and lower than $10 \mathrm{nM}$ for PC12 cells.

\section{Discussion}

There have been numerous toxicological studies on PBDEs using in vitro culture cells, such as MCF-7, HepG2, H295R and PC12 cells. However, none of these studies have determined the PBDEs concentration in the cells following exposure. The toxicological effects observed in these studies have been directly correlated to the exposure concentration of PBDEs in culture media rather than the final PBDEs burden in the cells. In this study, we measured for the first time PBDEs burdens in cells following exposure and associated PBDEs burdens in cells with exposure concentrations in culture media. It should be noted that the detection of PBDEs 
Table 1

Literature data on concentrations of PBDEs (ng/g wet-weight) in biotic tissues in the general environment and PBDEs-polluted areas.

\begin{tabular}{|c|c|c|c|c|c|c|}
\hline & Matrix & Country/area & Sampling years & Total PBDEs & Mean/median & Reference \\
\hline $\mathrm{G}^{\mathrm{a}}$ & Fish, beef, pork, chick meat & Japan & & $0.018-1.72$ & & Ohta et al. (2002) \\
\hline G & Maternal and cord blood plasma & Stockholm, Sweden & 2000-2001 & $0.001-0.058$ & 0.024 & Guvenius et al. (2003) \\
\hline G & Glaucous gull & Svalbard and Bjørnøya & 1995-1999 & $2.0-25.0$ & & Herzke et al. (2003) \\
\hline G & Fish liver, muscle & Belgian north sea & & $0.06-128.0$ & & Voorspoels et al. (2003) \\
\hline $\mathrm{G}$ & Salmon muscle & Canadian & 2002 & $0.14-5.5$ & 1.5 & Tittlemier et al. (2004) \\
\hline G & Trout liver, muscle & Greenland and European & 2000-2001 & $0.069-11.0$ & & Vives et al. (2004) \\
\hline G & Black guillemot liver & Greenland & 2000 & $0.66-9.5$ & 1.71 & Vorkamp et al. (2004) \\
\hline G & Fish muscle & Kahramanmaras, Turkey & 2003 & $\mathrm{nd}^{\mathrm{c}}-6.7$ & & Erdogrul et al. (2005) \\
\hline \multirow[t]{3}{*}{ G } & Gibel carp liver & & & nd -12.0 & & \\
\hline & Carp liver & Belgium & 2002 & $0.3-7.3$ & 1.0 & Hoff et al. (2005) \\
\hline & Eel liver & & & $0.8-39.8$ & 5.2 & \\
\hline \multirow[t]{2}{*}{ G } & Polar bear liver & Beaufort Sea, Alaska & 1993-2002 & $<0.2-2.0$ & $1.0 / 0.82$ & Kannan et al. (2005) \\
\hline & & Chukchi Sea, Alaska & & $<0.2-2.7$ & $0.88 / 0.60$ & \\
\hline \multirow[t]{2}{*}{ G } & Glaucous gull plasma & Norwegian Arctic & 2004 & $8.23-67.5$ & & Verreault et al. (2005) \\
\hline & Polar bear plasma & & 2002 & $2.65-9.72$ & 5.38 & \\
\hline G & Rock cod muscle & Ross Sea, Antarctica & 2000-2002 & $0.02-0.06$ & 0.05 & Corsolini et al. (2006) \\
\hline \multirow[t]{2}{*}{ G } & Buzzard muscle & Flanders, Belgium & $2003-2004$ & $0.4-104$ & 5.7 & Jaspers et al. (2006) \\
\hline & Buzzard liver & & & $<0.1-310$ & 2.8 & \\
\hline G & Bald eagle plasma & British Columbia & 2001-2003 & $0.62-18.87$ & 4.73 & McKinney et al. (2006) \\
\hline G & Salmon tissue & Southern Chile & 2004 & $0.9-2.0$ & 1.46 & Montory and Barra (2006) \\
\hline G & Poultry, beef, pork & Texas, America & 2003-2004 & $0.041-1.28$ & & Schecter et al. (2006) \\
\hline G & Glaucous gull plasma & Bear Island, Norwegian Arctic & 2002 & $3.1-71.8$ & 17.36 & Verreault et al. (2006) \\
\hline G & Penguin blood & Antarctica & 2004 & $0.002-1.726$ & & Corsolini et al. (2007) \\
\hline G & Fish & America & $2003-2004$ & $0.04-38.0$ & & Hayward et al. (2007) \\
\hline \multirow[t]{3}{*}{ G } & Bream muscle & Czech Rivers & 2005 & $3.2-20.8$ & $9.8 / 9.5$ & Hajslová et al. (2007) \\
\hline & Chub muscle & & & $0.9-36.0$ & $7.5 / 4.9$ & \\
\hline & Perch muscle & & & $0.9-6.8$ & $3.8 / 3.9$ & \\
\hline \multirow[t]{3}{*}{ G } & Polar cod liver & Barents Sea east of Svalbard & 2004 & $0.88-2.24$ & $1.50 / 1.50$ & Haukas et al. (2007) \\
\hline & Black guillemot liver & & & $1.55-6.33$ & $3.45 / 2.91$ & \\
\hline & Glaucous gull liver & & & $19.9-186$ & $59.1 / 41.4$ & \\
\hline \multirow[t]{4}{*}{ G } & Buzzard brain & Switzerland & 2003-2005 & nd-31 & & Naert et al. (2007) \\
\hline & Sparrow hawk brain & & & $4.6-168$ & & \\
\hline & Cormorant brain & & & nd -1.3 & & \\
\hline & Blackbird brain & & & nd-27 & & \\
\hline G & Glaucous gull plasma & Bear Island, Norwegian Arctic & 2004 & $8.23-67.5$ & 20.23 & Verreault et al. (2007a) \\
\hline G & Glaucous gull plasma & Norwegian Arctic & 2006 & $2.49-54.5$ & 12.52 & Verreault et al. (2007b) \\
\hline G & Fish muscle & Western US Parks & 2003-2005 & $0.01-9.5$ & 1.1 & Ackerman et al. (2008) \\
\hline G & Antarctic fish muscle, liver & Ross Sea, Antarctica & 2005 & $0.001-1.1$ & & Borghesi et al. (2008) \\
\hline \multirow[t]{2}{*}{ G } & Swordfish muscle & Southern Thyrrenian Sea, Italy & 2005 & $<0.004-1.91$ & $0.612 / 0.387$ & Corsolini et al. (2008) \\
\hline & Swordfish liver & & & $0.225-11.206$ & $2.218 / 0.916$ & \\
\hline G & Polar bear blood & East, Greenland & 1999-2001 & $0.5-1.9$ & 1.2 & Gebbink et al. (2008) \\
\hline & Polar bears brain & & & $<0.5-7.6$ & 2.9 & \\
\hline & Polar bears liver & & & $14-103$ & 40 & \\
\hline G & Sea otters liver & America & 1995-1998 & $0.5-63$ & 31.7 & Kannan et al. (2008) \\
\hline G & Lynx liver & Norway & 1993-2002 & $0.14-12.24$ & & Mariussen et al. (2008) \\
\hline & Grouse liver & & $1990-2000$ & $0.021-0.326$ & & \\
\hline & Moose liver & & 1995 & nd- 0.047 & & \\
\hline & Deer liver & & 1995-1996 & $0.039-0.106$ & & \\
\hline G & Catfish fillet & Southern Mississippi & 2006 & $0.3-11.4$ & & Staskal et al. (2008) \\
\hline G & Flat fish muscle & Scotland & 2004 & nd-1.67 & & Webster et al. (2008) \\
\hline & Plaice liver & & 1999-2005 & $2.08-65.64$ & & \\
\hline & Trout liver & & 2005 & $1.11-9.59$ & & \\
\hline & Trout muscle & & $2002-2005$ & nd-1.22 & & \\
\hline G & Ringed seal liver & Svalbard & 2007 & $0.33-4.5$ & 1.1 & Routti et al. (2009) \\
\hline & & Baltic & $2002-2007$ & $2.8-35.0$ & 7.1 & \\
\hline $\mathrm{P}^{\mathrm{b}}$ & Freshwater fish fillet & Washington State & 1997 & nd-174 & & Johnson and Olson (2001) \\
\hline $\mathrm{P}$ & Fish muscle & Scheldt Estuary & & $0.08-6.9$ & & Voorspoels et al. (2003) \\
\hline & Fish liver & & & $15-984$ & & \\
\hline$P$ & Fish muscle & Cinca River, Spain & 2002 & $0.2-436$ & & Eljarrat et al. (2004) \\
\hline & Fish liver & & & $0.1-446$ & & \\
\hline$P$ & Pelagic fish plasma & Detroit River & 2001-2002 & $0.932-9.124$ & & Valters et al. (2005) \\
\hline & Benthic fish plasma & & & $0.155-21.069$ & & \\
\hline$P$ & Bald eagle plasma & Southern California & 2001-2003 & & 30.91 & McKinney et al. (2006) \\
\hline$P$ & Sea otter liver & California Coast & 1992-2002 & $0.2-862$ & $82.8 / 27.2$ & Kannan et al. (2007) \\
\hline$P$ & Tilapia, bighead carp & Guiyu and Hong Kong & 2004 & $3.84-2687$ & & Luo et al. (2007a) \\
\hline $\mathrm{P}$ & Grass carp muscle & Nanyang River, Guiyu, China & 2007 & $45.2-53.1$ & & Luo et al. (2007b) \\
\hline & Mud carp muscle & & & $48.0-96.0$ & & \\
\hline & Crucian carp muscle & & & $70.9-570.0$ & & \\
\hline & Silver carp muscle & & & $89.8-614.9$ & & \\
\hline & Carp muscle & & & $458.1-765.9$ & & \\
\hline$P$ & Herring gull brain & Great Lakes, Ganada & 1991, 2003 & $15.44-142.65$ & & Crump et al. (2008) \\
\hline $\mathrm{P}$ & Hen kidney & Taizhou, China & 2006 & $10.0-67.2$ & 48 & Liang et al. (2008) \\
\hline & Hen spleen & & & $48.2-226.3$ & 155 & \\
\hline $\mathrm{P}$ & Plaice liver & Scotland & 1996-2005 & $4.1-536.1$ & & Webster et al. (2008) \\
\hline
\end{tabular}

${ }^{\text {a }}$ G: general environment.

b P: PBDEs-polluted area.

${ }^{\mathrm{c}}$ nd: levels below limit of detection. 
Table 2

BDE-47 accumulation (ng/g wet-weight) in cells following exposure to BDE-47.

\begin{tabular}{|c|c|c|c|c|c|c|c|c|}
\hline \multirow[t]{2}{*}{ Treatment } & \multicolumn{2}{|l|}{ MCF-7 } & \multicolumn{2}{|l|}{ HepG2 } & \multicolumn{2}{|l|}{ H295R } & \multicolumn{2}{|l|}{ PC12 } \\
\hline & 3 days & 6 days & 3 days & 6 days & 3 days & 6 days & 3 days & 6 days \\
\hline 0 & $\mathrm{nd}^{\mathrm{a}}$ & nd & nd & nd & nd & nd & nd & nd \\
\hline $0.1 \mathrm{nM}$ & $1.84 \pm 0.87$ & $3.59 \pm 0.92$ & $2.89 \pm 0.30$ & $7.16 \pm 2.76$ & $0.96 \pm 0.21$ & $7.81 \pm 1.74$ & $14.02 \pm 2.04$ & $15.35 \pm 2.24$ \\
\hline $1.0 \mathrm{nM}$ & $18.21 \pm 4.69$ & $43.26 \pm 11.14$ & $27.5 \pm 11.19$ & $52.15 \pm 18.04$ & $18.14 \pm 4.95$ & $43.46 \pm 16.74$ & $128.47 \pm 33.09$ & $142.70 \pm 36.75$ \\
\hline $10.0 \mathrm{nM}$ & $204.56 \pm 45.97$ & $698.96 \pm 157.08$ & $319.01 \pm 81.35$ & $701.62 \pm 178.21$ & $225.38 \pm 58.58$ & $726.68 \pm 232.03$ & $1557.67 \pm 350.06$ & $1757.43 \pm 394.93$ \\
\hline $100.0 \mathrm{nM}$ & $3021.87 \pm 543.94$ & & $4080.41 \pm 770.95$ & & $2897.24 \pm 501.27$ & & $6263.29 \pm 1034.22$ & \\
\hline
\end{tabular}

a nd: levels below limit of detection.

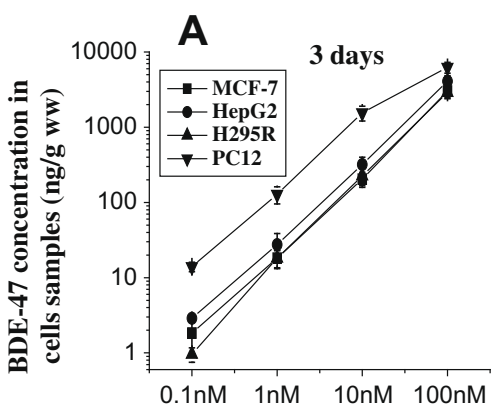

BDE-47 concentration in media

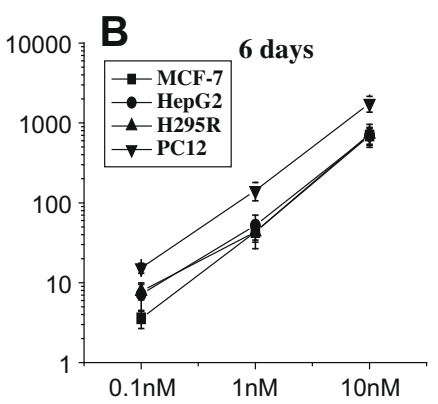

BDE-47 concentration in media

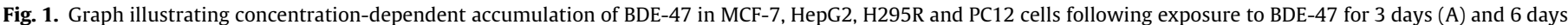
(B)
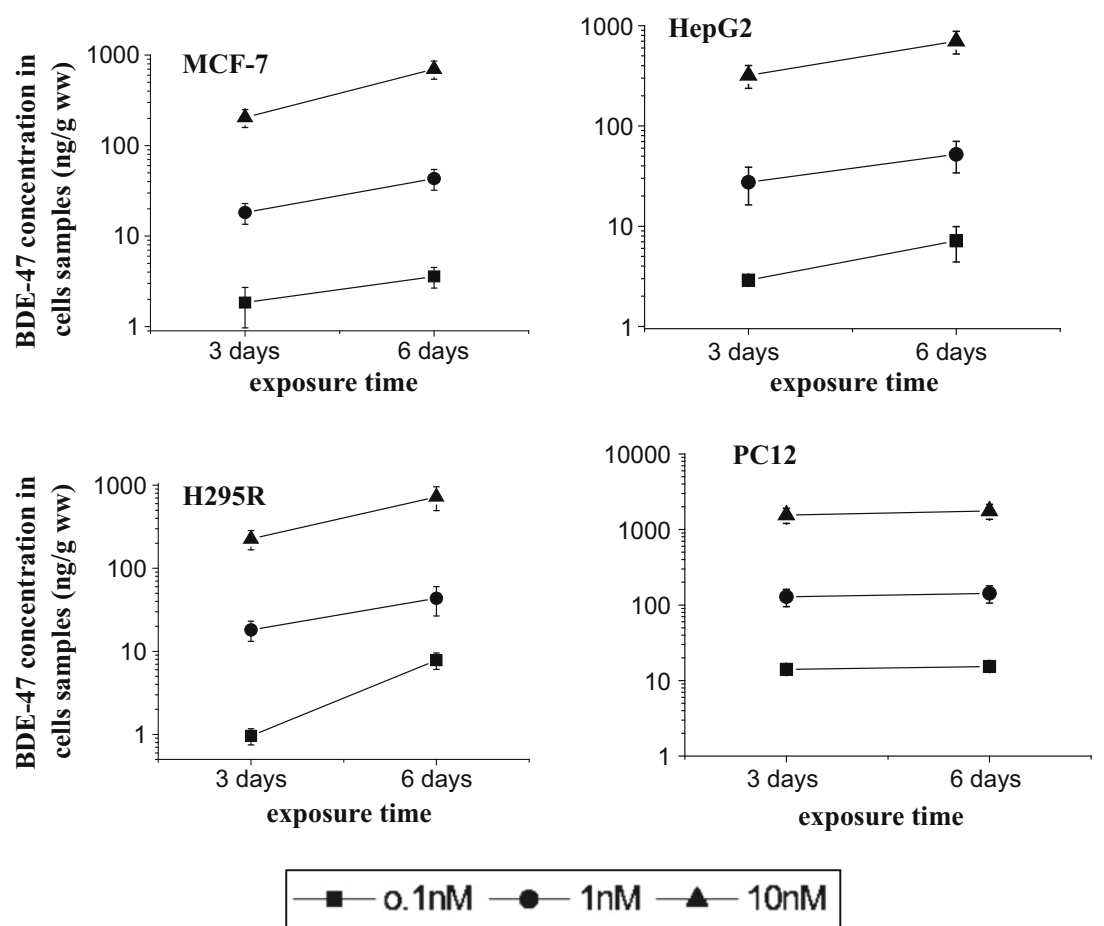

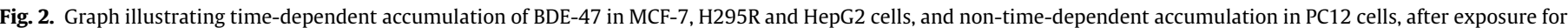
3 days and 6 days at the same exposure concentrations.

within a cell does not provide an indication of the tissue PBDEs concentrations. This is because not all the PBDEs will have entered the cells, as it is possible that many have only absorbed onto the cell surface. Similarly, with the literature data on PBDEs in biotic tissues, all the PBDEs detected in the tissues do not necessarily enter the cells. In this manner the data on PBDEs burdens in cells and the data on PBDEs burdens in biotic tissues are similarly incomplete. So, PBDEs burdens in cells in this study had comparability with PBDEs burdens in biotic tissues in the literature.

In this study, as expected, we found a concentration-dependent accumulation of BDE-47 in all cells. The accumulation of BDE-47 with increased exposure concentration suggested that BDE-47 
Table 3

Summary of literature data as percentiles of PBDEs levels (ng/g wet-weight) in biotic tissues in the general environment and polluted areas.

\begin{tabular}{|c|c|c|c|c|c|c|}
\hline & Minimum & 25 th & 50th & 75th & 90th & Maximum \\
\hline General environment & 0 & 0.16 & 1.81 & 10.68 & 55.35 & 310 \\
\hline Polluted area & 0 & 6.90 & 48.20 & 436.00 & 675.30 & 2687 \\
\hline
\end{tabular}

accumulation did not reach saturation in the exposure concentration range 0.1-100 nM. This indicates that a highest exposure concentration should be limited so that PBDEs burdens in cells do not largely exceed typical PBDEs environmental exposure levels. We found that BDE-47 concentrations in MCF-7, HepG2 and H295R cells exposed to $1 \mathrm{nM}$ BDE- 47 for 3 days reached environmental exposure levels typical of biotic tissues from the general environment. This was even more pronounced for cells exposed to $1 \mathrm{nM}$ BDE-47 for 6 days. In PC12 neuronal cells, exposure to $1 \mathrm{nM}$ BDE47 for 3-6 days resulted in PBDEs burdens that were higher than the environmentally relevant level. Results from previous studies have shown that exposure to 0.01-10 $\mu \mathrm{M}$ PBDEs for 2-6 days will result in much higher PBDEs burdens in cells than typical environmental exposure levels in biotic tissues. In summary, to ascertain the ecotoxic and health risks of PBDEs we suggest that the highest concentrations of PBDEs in culture media should be $<10 \mathrm{nM}$ for PC12 cells and approximately $10 \mathrm{nM}$ for other cells. These guidelines apply even when considering PBDE-polluted regions with high PBDEs burdens.

Although it is not a new concept, the study of environmentally relevant doses (concentrations) has been the focus of recent attention (Bardullas et al., 2009; Kozul et al., 2009). Myers et al. (2009) concluded that high dose experiments could not be used to predict low dose results. They also suggested that previous acceptable exposure levels for some toxicants that were based on high dose results should be reevaluated in environmentally relevant dose studies, especially for those involving the endocrine system. The National Institute of Environmental Health Sciences (NIEHS) is also focusing on the environmentally relevant dose (Birnbaum, 2009). In this study, our results provide an approximate reference to choose an environmentally relevant exposure concentration of PBDEs for in vitro studies. PBDEs concentrations in cells following exposure will vary among different studies due to diversity in exposure conditions and times. Thus, we suggest that during in vitro toxicological studies on PBDEs the final concentration of PBDEs in the cells should be determined after exposure, which will facilitate explanation of the dose-response relationship and environmental significance.

It is known that there are small differences in PBDEs accumulation among different cell lines. However, it was an unexpected result that PC12 neuronal cells had a BDE-47 accumulation approximately one order of magnitude higher than other cells after 3 days exposure at the same exposure concentration. This suggests that PC12 cells can accumulate BDE-47 more rapidly than other cells. PBDEs accumulation in MCF-7, H295R and HepG2 cells increased with exposure time. However, BDE-47 accumulation in PC12 cells was not time-dependent with similar concentrations observed after exposure for 3 days and 6 days at the same exposure concentration. BDE-47 accumulation in PC12 cells was rapid and reached a plateau within 3 days of exposure, whereas accumulation in MCF-7, HepG2 and H295R cells did not reach a plateau even after 6 days. Increasing the BDE-47 exposure concentration by one order of magnitude (0.1-100 nM) caused a comparable increase in the BDE-47 burdens in MCF-7, HepG2 and H295R cells but not to saturation. Between 0.1 and $10 \mathrm{nM}$, BDE-47 accumulation in PC12 cells increased comparably to the order of magnitude by which the exposure concentration was increased. However, when the exposure concentration was increased to $100 \mathrm{nM}$, the
BDE-47 burden in PC12 cells was four times higher than the value for exposure at $10 \mathrm{nM}$ (Fig. 1). This may suggest that BDE-47 saturation could occur with a further increase in exposure concentration. These results suggest that neuronal cells might have different accumulation kinetics from epithelia cells. Mundy et al. (2004) reported that the accumulation of BDE- 47 in primary cultures of rat neocortical cells in vitro increased linearly with time for the first $60 \mathrm{~min}$. Between 90 and $120 \mathrm{~min}$ the rate of accumulation decreased and saturation began at 120 min. Further studies could investigate why PBDE accumulation in neural cells in vitro can reach a plateau within a short time, and whether this phenomenon occurs in vivo. This could aid understanding of PBDEs accumulation in the brain and its neurotoxicity. Furthermore, the results could be helpful for choosing exposure concentration and exposure time for in vitro and in vivo toxicological studies on PBDEs.

\section{Conclusion}

In vitro exposure to $1 \mathrm{nM}$ BDE-47 for up to 6 days resulted in environmentally relevant burdens in MCF-7, HepG2 and H295R cells and much higher burdens in neuronal PC12 cells. To investigate toxicity of PBDEs at an environmentally relevant concentration, we suggest that the highest PBDEs exposure concentrations should be $<10 \mathrm{nM}$ for PC12 cells and approximately $10 \mathrm{nM}$ for other cells. These guidelines are applicable even when considering exposure in PBDE-polluted areas. In vitro toxicological studies measuring the PBDEs burdens in cells after exposure are necessary to investigate the dose-response relationship and environmental significance. We found that PBDEs accumulation reached a plateau within a short time in PC12 cells but not in other cells, which suggests that neuronal cells might have different accumulation kinetics to other cells.

\section{Acknowledgments}

We would like to thank Professor Ana M. Soto (Tufts University School of Medicine) for generously providing MCF-7 cells. This work was supported by grants from the Knowledge Innovation Program of the Chinese Academy of Sciences (KZCX2-YW-420-3 and KZCX2-YW-Q-02-05) and the National Natural Science Foundation of China (20437020 and 20677074).

\section{References}

Ackerman, L.K., Schwindt, A.R., Simonich, S.L.M., Koch, D.C., Blett, T.F., Schreck, C.B., Kent, M.L., Landers, D.H., 2008. Atmospherically deposited PBDEs, pesticides, PCBs, and PAHs in western US national park fish: concentrations and consumption guidelines. Environmental Science \& Technology 42, 2334-2341.

Alcock, R.E., Sweetman, A.J., Prevedouros, K., Jones, K.C., 2003. Understanding levels and trends of BDE-47 in the UK and North America: an assessment of principal reservoirs and source inputs. Environment International 29,691-698.

Andrade, A.J.M., Grande, S.W., Talsness, C.E., Grote, K., Chahoud, I., 2006. A doseresponse study following in utero and lactational exposure to di-(2-ethylhexyl)phthalate (DEHP): non-monotonic dose-response and low dose effects on rat brain aromatase activity. Toxicology 227, 185-192.

Barber, J.L., Walsh, M.J., Hewitt, R., Jones, K.C., Martin, F.L., 2006. Low-dose treatment with polybrominated diphenyl ethers (PBDEs) induce altered characteristics in MCF-7 cells. Mutagenesis 21, 351-360.

Bardullas, U., Limón-Pacheco, J.H., Giordano, M., Carrizales, L., Mendoza-Trejo, M.S., Rodríguez, V.M., 2009. Chronic low-level arsenic exposure causes gender- 
specific alterations in locomotor activity, dopaminergic systems, and thioredoxin expression in mice. Toxicology and Applied Pharmacology 239, 169-177.

Birnbaum, L.S., 2009. Applying research to public health questions: timing and environmentally relevant dose. Environmental Health Perspectives 117, A478.

Borghesi, N., Corsolini, S., Focardi, S., 2008. Levels of polybrominated diphenyl ethers (PBDEs) and organochlorine pollutants in two species of Antarctic fish (Chionodraco hamatus and Trematomus bernacchii). Chemosphere 73, 155-160.

Cantón, R.F., Sanderson, J.T., Nijmeijer, S., Bergman, Å., Letcher, R.J., Van Den Berg, M., 2006. In vitro effects of brominated flame retardants and metabolites on CYP17 catalytic activity: a novel mechanism of action? Toxicology and Applied Pharmacology 216, 274-281.

Chen, Q., Garabrant, D.H., Hedgeman, E., Little, R.J., Elliott, M.R., Gillespie, B., Hong, B., Lee, S.Y., Lepkowski, J.M., Franzblau, A., Adriaens, P., Demond, A.H., Patterson Jr., D.G., 2010. Estimation of background serum 2,3,7,8-TCDD concentrations by using quantile regression in the UMDES and NHANES populations. Epidemiology doi:10.1097/EDE.0b013e3181ce9550.

Corsolini, S., Borghesi, N., Schiamone, A., Focardi, S., 2007. Polybrominated diphenyl ethers, polychlorinated dibenzo-dioxins, -furans, and -biphenyls in three species of Antarctic penguins. Environmental Science and Pollution Research 14, 421-429.

Corsolini, S., Covaci, A., Ademollo, N., Focardi, S., Schepens, P., 2006. Occurrence of organochlorine pesticides (OCPs) and their enantiomeric signatures, and concentrations of polybrominated diphenyl ethers (PBDEs) in the Adélie penguin food web, Antarctica. Environmental Pollution 140, 371-382.

Corsolini, S., Guerranti, C., Perra, G., Focardi, S., 2008. Polybrominated diphenyl ethers, perfluorinated compounds and chlorinated pesticides in swordfish (Xiphias gladius) from the Mediterranean Sea. Environmental Science \& Technology 42, 4344-4349.

Costa, L.G., Giordano, G., 2007. Developmental neurotoxicity of polybrominated diphenyl ether (PBDE) flame retardants. Neurotoxicology 28, 1047-1067.

Crump, D., Jagla, M.M., Kehoe, A., Kennedy, S.W., 2008. Detection of polybrominated diphenyl ethers in herring gull (Larus argentatus) brains: effects on mRNA expression in cultured neuronal cells. Environmental Science \& Technology 42 , 7715-7721.

Darnerud, P.O., Eriksen, G.S., Jóhannesson, T., Larsen, P.B., Viluksela, M., 2001. Polybrominated diphenyl ethers: occurrence, dietary exposure and toxicology. Environmental Health Perspectives 109, 49-68.

Dingemans, M.M.L., de Groot, A., van Kleef, R.G.D.M., Bergman, Å., van den Berg, M., Vijverberg, H.P.M. Westerink, R.H.S., 2008. Hydroxylation increases the neurotoxic potential of BDE-47 to affect exocytosis and calcium homeostasis in PC12 cells. Environmental Health Perspectives 116, 637-643.

Dingemans, M.M.L., Ramakers, G.M.J., Gardoni, F., van Kleef, R.G.D.M., Bergman, Å., Di Luca, M., van den Berg, M., Westerink, R.H.S., Wijverberg, H.P.M., 2007. Neonatal exposure to brominated flame retardant BDE-47 reduces long-term potentiation and postsynaptic protein levels in mouse hippocampus. Environmental Health Perspectives 115, 865-870.

Eljarrat, E., de la Cal, A., Raldua, D., Duran, C., Barceló, D., 2004. Occurrence and bioavailability of polybrominated diphenyl ethers and hexabromocyclododecane in sediment and fish from the Cinca River, a tributary of the Ebro River (Spain). Environmental Science \& Technology 38, 2603-2608.

Erdogrul, O., Covac, A., Schepens, P., 2005. Levels of organochlorine pesticides, polychlorinated biphenyls and polybrominated diphenyl ethers in fish species from Kahramanmaras, Turkey. Environment International 31, 703-711.

Fery, Y., Buschauer, I., Salzig, C., Lang, P., Schrenk, D., 2009. Technical pentabromodiphenyl ether and hexabromocyclododecane as activators of the pregnane-X-receptor (PXR). Toxicology 264, 45-51.

Frederiksen, M., Vorkamp, K., Thomsen, M., Knudsen, L.E., 2009. Human internal and external exposure to PBDEs - a review of levels and sources. International Journal of Hygiene and Environmental Health 212, 109-134.

Gauthier, L.T., Hebert, C.E., Weseloh, D.V., Letcher, R.J., 2008. Dramatic changes in the temporal trends of polybrominated diphenyl ethers (PBDEs) in herring gull eggs from the Laurentian Great Lakes: 1982-2006. Environmental Science \& Technology 42, 1524-1530.

Gebbink, W.A., Sonne, C., Dietz, R., Kirkegaard, M., Riget, F.F., Born, E.W., Muir, D.C., Letcher, R.J., 2008. Tissue-specific congener composition of organohalogen and metabolite contaminants in East Greenland polar bears (Ursus maritimus). Environmental Pollution 152, 621-629.

Gill, U., Chu, I., Ryan, J.J., Feeley, M., 2004. Polybrominated diphenyl ethers: human tissue levels and toxicology. Reviews of Environmental Contamination and Toxicology 183, 55-97.

Giordano, G., Kavanagh, T.J., Costa, L.G., 2009. Mouse cerebellar astrocytes protect cerebellar granule neurons against toxicity of the polybrominated diphenyl ether (PBDE) mixture DE-71. Neurotoxicology 30, 326-329.

Giordano, G., Kavanagh, T.J., Costa, L.G., 2008. Neurotoxicity of a polybrominated diphenyl ether mixture (DE-71) in mouse neurons and astrocytes is modulated by intracellular glutathione levels. Toxicology and Applied Pharmacology 232, 161-168.

Guvenius, D.M., Aronsson, A., Ekman-Ordeberg, G., Bergman, A., Noren, K., 2003. Human prenatal and postnatal exposure to polybrominated diphenyl ethers, polychlorinated biphenyls, polychlorobiphenylols, and pentachlorophenol. Environmental Health Perspectives 111, 1235-1241.

Hajslová, J., Pulkrabová, J., Poustka, J., Cajka, T., Randák, T., 2007. Brominated flame retardants and related chlorinated persistent organic pollutants in fish from river Elbe and its main tributary Vltava. Chemosphere 69, 1195-1203.
Hallgren, S., Darnerud, P.O., 2002. Polybrominated diphenyl ethers (PBDEs), polychlorinated biphenyls (PCBs) and chlorinated paraffins (CPs) in ratstesting interactions and mechanisms for thyroid hormone effects. Toxicology $177,227-243$.

Harju, M., Hamers, T., Kamstra, J.H., Sonneveld, E., Boon, J.P., Tysklind, M. Andersson, P.L., 2007. Quantitative structure-activity relationship modeling on in vitro endocrine effects and metabolic stability involving 26 selected brominated flame retardants. Environmental Toxicology and Chemistry 26, 816-826.

Haukas, M., Berger, U., Hop, H., Gulliksen, B., Gabrielsen, G.W., 2007. Bioaccumulation of per- and polyfluorinated alkyl substances (PFAS) in selected species from the Barents Sea food web. Environmental Pollution 148 360-371.

Hayward, D., Wong, J., Krynitsky, A.J., 2007. Polybrominated diphenyl ethers and polychlorinated biphenyls in commercially wild caught and farm-raised fish fillets in the United States. Environmental Research 103, 46-54.

He, P., Wang, A.G., Xia, T., Gao, P., Niu, Q., Guo, L.J., Xu, B.Y., Chen, X.M., 2009 Mechanism of the neurotoxic effect of PBDE-47 and interaction of PBDE-47 and PCB153 in enhancing toxicity in SH-SY5Y cells. Neurotoxicology 30, 10-15.

He, W.H., He, P., Wang, A.G., Xia, T., Xu, B.Y., Chen, X.M., 2008a. Effects of PBDE-47 on cytotoxicity and genotoxicity in human neuroblastoma cells in vitro. Mutation Research 649, 62-70.

He, Y.H., Murphy, M.B., Yu, R.M.K., Lam, M.H.W., Hecker, M., Giesy, J.P., Wu, R.S.S. Lam, P.K.S., 2008b. Effects of 20 PBDE metabolites on steroidogenesis in the H295R cell line. Toxicology Letters 176, 230-238.

Helgason, L.B., Polder, A., Føreid, S., Baek, K., Lie, E., Gabrielsen, G.W., Barrett, R.T. Skaare, J.U., 2009. Levels and temporal trends (1983-2003) of polybrominated diphenyl ethers and hexabromocyclododecanes in seabird eggs from north Norway. Environmental Toxicology \& Chemistry 28, 1096-1103.

Herzke, D., Gabrielsen, G.W., Evenset, A., Burkow, I.C., 2003. Polychlorinated camphenes (toxaphenes), polybrominated diphenylethers and other halogenated organic pollutants in glaucous gull (Larus hyperboreus) from Svalbard and Bjørnøya (Bear Island). Environmental Pollution 121, 293-300.

Hites, R.A., 2004. Polybrominated diphenyl ethers in the environment and in people: a meta-analysis of concentrations. Environmental Science \& Technology 38, 945-956.

Hoff, P.T., Van Campenhout, K., Van de Vijver, K., Covaci, A., Bervoets, L., Moens, L., Huyskens, G., Goemans, G., Belpaire, C., Blust, R., De Coen, W., 2005 Perfluorooctane sulfonic acid and organohalogen pollutants in liver of three freshwater fish species in Flanders (Belgium): relationships with biochemical and organismal effects. Environmental Pollution 137, 324-333.

Hu, X.Z., Xu, Y., Hu, D.C., Hui, Y., Yang, F.X., 2007. Apoptosis induction on human hepatoma cells HepG2 of decabrominated diphenyl ether (PBDE-209). Toxicology Letters $171,19-28$.

Isosaari, P., Hallikainen, A., Kiviranta, H., Vuorinen, P.J., Parmanne, R., Koistinen, J. Vartiainen, T., 2006. Polychlorinated dibenzo-p-dioxins, dibenzofurans, biphenyls, naphthalenes and polybrominated diphenyl ethers in the edible fish caught from the Baltic Sea and lakes in Finland. Environmental Pollution $141,213-225$.

Jaspers, V.L., Voorspoels, S., Covaci, A., Eens, M., 2006. Can predatory bird feathers be used as a non-destructive biomonitoring tool of organic pollutants? Biology Letters 2, 283-285.

Johnson, A., Olson, N., 2001. Analysis and occurrence of polybrominated diphenyl ethers in Washington State freshwater fish. Archives of Environmental Contamination and Toxicology 41, 339-344.

Kannan, K., Moon, H.B., Yun, S.H., Agusa, T., Thomasd, N.J., Tanabe, S., 2008 Chlorinated, brominated, and perfluorinated compounds, polycyclic aromatic hydrocarbons and trace elements in livers of sea otters from California, Washington, and Alaska (USA), and Kamchatka (Russia). Journal of Environmental Monitoring 10, 552-558.

Kannan, K., Perrotta, E., Thomas, N.J., Aldous, K.M., 2007. A comparative analysis of polybrominated diphenyl ethers and polychlorinated biphenyls in southern sea otters that died of infectious diseases and noninfectious causes. Archives of Environmental Contamination and Toxicology 53, 293-302.

Kannan, K., Yun, S.H., Evans, T.J., 2005. Chlorinated, brominated, and perfluorinated contaminants in livers of polar bears from Alaska. Environmental Science \& Technology 39, 9057-9063.

Kozul, C.D., Ely, K.H., Enelow, R.I., Hamilton, J.W., 2009. Low-dose arsenic compromises the immune response to influenza a infection in vivo. Environmental Health Perspectives 117, 441-1447.

Liang, S.X., Zhao, Q., Qin, Z.F., Zhao, X.R., Yang, Z.Z., Xu, X.B., 2008. Levels and distribution of polybrominated diphenyl ethers in various tissues of foraging hens from an electronic waste recycling area in South China. Environmental Toxicology and Chemistry 27, 1279-1283.

Luo, Q., Cai, Z.W., Wong, M.H., 2007a. Polybrominated diphenyl ethers in fish and sediment from river polluted by electronic waste. Science of the Total Environment 383, 115-127.

Luo, Q., Wong, M.H., Cai, Z.W., 2007b. Determination of polybrominated diphenyl ethers in freshwater fishes from a river polluted by e-wastes. Talanta 72, 16441649.

Madia, F., Giordano, G., Fattori, V., Vitalone, A., Branchi, I., Capone, F., Costa, L.G., 2004. Differential in vitro neurotoxicity of the flame retardant PBDE-99 and of the PCB Aroclor 1254 in human astrocytoma cells. Toxicology Letters 154, 1121

Mariussen, E., Steinnes, E., Breivik, K., Nygård, T., Schlabach, M., Kålås, J.A., 2008. Spatial patterns of polybrominated diphenyl ethers (PBDEs) in mosses, 
herbivores and a carnivore from the Norwegian terrestrial biota. Science of the Total Environment 404, 162-170.

McKinney, M.A., Cesh, L.S., Elliott, J.E., Williams, T.D., Garcelon, D.K., Letcher, R.J., 2006. Brominated flame retardants and halogenated phenolic compounds in North American west coast bald eaglet (Haliaeetus leucocephalus) plasma. Environmental Science \& Technology 40, 6275-6281.

Mercado-Feliciano, M., Bigsby, R.M., 2008. The polybrominated diphenyl ether mixture DE-71 is mildly estrogenic. Environmental Health Perspectives 116, 605-611.

Montory, M., Barra, Ricardo, 2006. Preliminary data on polybrominated diphenyl ethers (PBDEs) in farmed fish tissues (Salmo salar) and fish feed in Southern Chile. Chemosphere 63, 1252-1260.

Mundy, W.R., Freudenrich, T.M., Crofton, K.M., DeVito, M.J., 2004. Accumulation of PBDE-47 in primary cultures of rat neocortical cells. Toxicological Sciences 82 , 164-169.

Myers, J.P., Zoeller, R.T., vom Saal, F.S., 2009. A clash of old and new scientific concepts in toxicity, with important implications for public health. Environmental Health Perspectives 117, 1652-1655.

Naert, C., Peteghem, C.V., Kupper, J., Jenni, L., Naegeli, H., 2007. Distribution of polychlorinated biphenyls and polybrominated diphenyl ethers in birds of prey from Switzerland. Chemosphere 68, 977-987.

Narita, S., Goldblum, R.M., Watson, C.S., Brooks, E.G., Estes, D.M., Curran, E.M., Midoro-Horiuti, T., 2007. Environmental estrogens induce mast cell degranulation and enhance IgE-mediated release of allergic mediators. Environmental Health Perspectives 115, 48-52.

Ohta, S., Ishizuka, D., Nishimura, H., Nakao, T., Aozasa, O., Shimidzu, Y, Ochiai, F. Kida, T., Nishi, M., Miyata, H., 2002. Comparison of polybrominated diphenyl ethers in fish, vegetables, and meats and levels in human milk of nursing women in Japan. Chemosphere 46, 689-696.

Peters, A.K., van Londen, K., Bergman, A., Bohonowych, J., Denison, M.S., van den Berg, M., Sanderson, J.T., 2004. Effects of polybrominated diphenyl ethers on basal and TCDD-induced ethoxyresorufin activity and cytochrome P450-1A1 expression in MCF-7, HepG2, and H4IIE cells. Toxicological Sciences 82, 488496.

Peters, A.K., van Londen, K., Bergman, A., Bohonowych, J., Denison, M.S., van den Berg, M., Sanderson, J.T., 2006. Interactions of polybrominated diphenyl ethers with the aryl hydrocarbon receptor pathway. Toxicological Sciences 92, 488496.

Routti, H., Letcher, R.J., Chu, S., Van Bavel, B., Gabrielsen, G.W., 2009 Polybrominated diphenyl ethers and their hydroxylated analogues in ringed seals (Phoca hispida) from Svalbard and the Baltic Sea. Environmental Science \& Technology 43, 3494-3499.

Schecter, A., Papke, O., Harris, T.R., Tung, K.C., Musumba, A., Olson, J., Birnbaum, L 2006. Polybrominated diphenyl ether (PBDE) levels in an expanded market basket survey of US food and estimated PBDE dietary intake by age and sex. Environmental Health Perspectives 114, 1515-1520.

Shaw, S.D., Kannan, K., 2009. Polybrominated diphenyl ethers in marine ecosystems of the American continents: foresight from current knowledge. Reviews on Environmental Health 24, 157-229.

Song, R.F., Duartea, T.L., Almeida, G.M., Farmer, P.B., Cooke, M.S., Zhang, W.B., Sheng G.Y., Fu, J.M., Jones, G.D.D., 2009. Cytotoxicity and gene expression profiling of two hydroxylated polybrominated diphenyl ethers in human H295R adrenocortical carcinoma cells. Toxicology Letters 185, 23-31.

Stapleton, H.M., Kelly, S.M., Pei, R., Letcher, R.J., Gunsch, C., 2009. Metabolism of polybrominated diphenyl ethers (PBDEs) by human hepatocytes in vitro. Environmental Health Perspectives 117, 197-202.

Staskal, D.F., Scott, L.L.F., Haws, L.C., Luksemburg, W.J., Birnbaum, L.S., Urban, J.D. Williams, E.S. Paustenbach, D.J. Harris, M.A. 2008. Assessment of polybrominated diphenyl ether exposures and health risks associated with consumption of southern Mississippi catfish. Environmental Science \& Technology 42, 6755-6761.

Stavenes Andersen, I., Voie, O.A., Fonnum, F., Mariussen, E., 2009. Effects of methyl mercury in combination with polychlorinated biphenyls and brominated flame retardants on the uptake of glutamate in rat brain synaptosomes: mathematical approach for the study of mixtures. Toxicological Sciences 112 $175-184$.

Streets, S.S., Henderson, S.A., Stoner, A.D., Carlson, D.L., Simcik, M.F., Swackhamer D.L., 2006. Partitioning and bioaccumulation of PBDEs and PCBs in Lake Michigan. Environmental Science \& Technology 40, 7263-7269.

Suvorov, A., Girard, S., Lachapelle, S., Abdelouahab, N., Sebire, G., Takser, L., 2008 Perinatal exposure to low-dose BDE-47, an emergent environmenta contaminant, causes hyperactivity in rat offspring. Neonatology 95, 203-209.
Suvorov, A., Takser, L., 2008. Facing the challenge of data transfer from animal models to humans: the case of persistent organohalogens. Environmental Health 7, 58 .

Tagliaferri, S., Caglieri, A., Goldoni, M., Pinelli, S., Alinovi, R., Poli, D., Pellacani, C., Giordano, G., Mutti, A., Costa, L.G., 2010. Low concentrations of the brominated flame retardants BDE-47 and BDE-99 induce synergistic oxidative stressmediated neurotoxicity in human neuroblastoma cells. Toxicology in Vitro 24, 116-122.

Talsness, C.E., Kuriyama, S.N., Sterner-Kock, A., Schnitker, P., Grande, S.W. Shakibaei, M., Andrade, A., Grote, K., Chahoud, I., 2008. In utero and lactational exposures to low doses of polybrominated diphenyl ether-47 alter the reproductive system and thyroid gland of female rat offspring. Environmental Health Perspectives 116, 308-314.

Tanabe, S., Ramu, K., Isobe, T., Takahashi, S., 2008. Brominated flame retardants in the environment of Asia-Pacific: an overview of spatial and temporal trends. Journal of Environmental Monitoring 10, 188-197.

Tittlemier, S.A., Forsyth, D., Breakell, K., Verigin, V., Ryan, J.J., Hayward, S., 2004. Polybrominated diphenyl ethers in retail fish and shellfish samples purchased from Canadian Markets. Journal of Agricultural and Food Chemistry 52, 77407745 .

Valters, K., Li, H., Alaee, M., D’Sa, I., Marsh, G., Bergman, A., Letcher, R.J., 2005. Polybrominated diphenyl ethers and hydroxylated and methoxylated brominated and chlorinated analogues in the plasma of fish from the Detroit River. Environmental Science \& Technology 39, 5612-5619.

Verreault, J., Bech, C., Letcher, R.J., Ropstad, E., Dahl, E., Gabrielsen, G.W., 2007a. Organohalogen contamination in breeding glaucous gulls from the Norwegian Arctic: associations with basal metabolism and circulating thyroid hormones. Environmental Pollution 145, 138-145.

Verreault, J., Gabrielsen, G.W., Chu, S., Muir, D.C., Andersen, M., Hamaed, A., Letcher, R.J., 2005. Flame retardants and methoxylated and hydroxylated polybrominated diphenyl ethers in two Norwegian Arctic top predators: glaucous gulls and polar bears. Environmental Science \& Technology 39, 6021-6028.

Verreault, J., Gebbink, W.A., Gauthier, L.T., Gabrielsen, G.W., Letcher, R.J., 2007b. Brominated flame retardants in glaucous gulls from the Norwegian Arctic: more than just an issue of polybrominated diphenyl ethers. Environmental Science \& Technology 41, 4925-4931.

Verreault, J., Letcher, R.J., Ropstad, E., Dahl, E., Gabrielsen, G.W., 2006. Organohalogen contaminants and reproductive hormones in incubating glaucous gulls (Larus hyperboreus) from the Norwegian Arctic. Environmental Toxicology \& Chemistry 25, 2990-2996.

Vives, I., Grimalt, J.O., Lacorte, S., Guillamón, M., Barceló, D., 2004. Polybromodiphenyl ether flame retardants in fish from lakes in European high mountains and Greenland. Environmental Science \& Technology 38, 2338-2344.

Voorspoels, S., Covaci, A., Schepens, P., 2003. Polybrominated diphenyl ethers in marine species from the Belgian North Sea and the Western Scheldt Estuary: levels, profiles, and distribution. Environmental Science \& Technology 2003, 348-4357.

Vorkamp, K., Christensen, J.H., Glasius, M., Riget, F.F., 2004. Persistent halogenated compounds in black guillemots (Cepphus grille) from Greenland--levels, compound patterns and spatial trends. Marine Pollution Bulletin 48, 111-121.

Watanabe, I., Sakai, S., 2003. Environmental release and behavior of brominated flame retardants. Environment International 29, 665-682.

Webster, L., Russell, M., Adefehinti, F., Dalgarno, E.J., Moffat, C.F., 2008. Preliminary assessment of polybrominated diphenyl ethers (PBDEs) in the Scottish aquatic environment, including the Firth of Clyde. Journal of Environmental Monitoring 10, 463-473.

Wetherill, Y.B., Petre, C.E., Monk, K.R., Puga, A., Knudsen, K.E., 2002. The xenoestrogen bisphenol a induces inappropriate androgen receptor activation and mitogenesis in prostatic adenocarcinoma cells. Molecular Cancer Therapeutics 1, 515-524.

Wozniak, A.L., Bulayeva, N.N., Watson, C.S., 2005. Xenoestrogens at picomolar to nanomolar concentrations trigger membrane estrogen receptor-alphamediated $\mathrm{Ca} 2+$ fluxes and prolactin release in GH3/B6 pituitary tumor cells. Environmental Health Perspectives 113, 431-439.

Wu, J.P., Luo, X.J., Zhang, Y., Luo, Y., Chen, S.J., Mai, B.X., Yang, Z.Y., 2008. Bioaccumulation of polybrominated diphenyl ethers (PBDEs) and polychlorinated biphenyls (PCBs) in wild aquatic species from an electronic waste (e-waste) recycling site in South China. Environment International 34, 1109-1113.

Zhang, M., He, W.M., He, P., Xia, T., Chen, X.M., Wang, A.G., 2007. Effects of PBDE-47 on oxidative stress and apoptosis in SH-SY5Y cells. Zhongua Lao Dong Wei Sheng Zhi Ye Bing Za Zhi 25, 145-147. 